\title{
KAJIAN FAKTOR-FAKTOR PENYEBAB DAN DAMPAK BANJIR DI KOTA BUKIT TINGGI
}

\author{
ZUHELDI $^{1}$, NURSYAIFI YULIU ${ }^{2}$, ZUHERNA MIZWAR $^{2}$ \\ Universitas Muhammadyah Sumatera Barat ${ }^{1}$, Universitas Bung Hatta ${ }^{2}$ \\ zhd.704@gmail.com ${ }^{1}$
}

\begin{abstract}
In recent years the city of Bukittinggi has often experienced flooding due to climate change and high population growth, tropical climate and unstable landforms and infrastructure development that is not environmentally sound. Therefore, there must be steps and efforts of various parties, including universities to find out things related to flooding. This study aims to identify, analyze and determine steps and efforts to manage flood that can be done on the factors causing and impact caused by the flood. flood disaster in the city of Bukittinggi. The method used in this research is descriptive quantitative. The types of data used are primary data and secondary data. Collecting data using a questionnaire with 45 questions distributed to 123 respondents, determining the number of respondents using purposive sampling method. Data processing using SPSS 16 software. The results of the validity test show that all valid variables can be seen from the $r$ value of the results for each item (variable) which is positive and the calculated $r$ value $>r$ table value is 0.1757 for a significant level of 5\%. The results of the reliability test show that all reliable variables can be seen from Cronbach's alpha value which is greater than the minimum Cronbach alpha value of 0.6 so that the data is quite reliable or reliable. The results of the KMO and Bartlett's tests have also met the requirements with a value greater than 0.5 with a significance value of 0.000. The results of the anti-image test resulted in 25 variables being used. Natural Factors, Human Factors, Economic Impacts, Social Impacts, Environmental Impacts. The most dominant factors are Natural Factors, Human Factors and Economic Impacts, to minimize these impacts, structural and nonstructural mitigation must be carried out.
\end{abstract}

Keywords: Flood, Cause, Impact.

Abstrak: Beberapa tahun terakhir kota Bukittinggi seringkali mengalami banjir akibat perubahan iklim dan pertumbuhan penduduk yang tinggi, iklim tropis dan bentuk lahan yang tidak stabil dan pembangunan infrastruktur yang kurang berwawasan lingkungan. Oleh sebab itu harus ada langkah dan upaya berbagai pihak, termasuk perguruan tinggi untuk mengetahui hal-hal yang berkaitan dengan banjir Penelitian ini bertujuan untuk mengidentifikasi, menganalisis serta menentukan langkah dan upaya pengelolaan banjir yang dapat dilakukan terhadap faktor-faktor penyebab dan dampak yang ditimbulkan oleh bencana banjir di kota Bukittinggi. Metode yang digunakan dalam penelitian ini adalah deskriptive kuantitatif. Jenis data yang digunakan adalah data primer dan data sekunder. Pengumpulan data menggunakan bantuan kuisioner dengan 45 butir pertanyaan yang disebar ke 123 orang responden, penentuan jumlah responden menggunakan metode purposive sampling. Pengolahan data menggunakan bantuan software SPSS 16. Hasil uji validitas memperlihatkan bahwa semua variabel valid terlihat dari dari nilai $r$ hasil untuk tiap item (variabel) bernilai positif dan nilai $r$ hitung $>$ nilai $\mathrm{r}$ tabel yaitu 0,1757 untuk taraf signifikan 5\%. Hasil uji reliabilitas memperlihatkan bahwa semua variabel reliabel terlihat dari nilai alpha cronbach'slebih besar dibandingkan dengan nilai minimal cronbach alfa 0,6 sehingga data cukup realibel atau handal. Hasil uji KMO dan Bartlett's juga telah memenuhi 
syarat dengan nilai lebih besar dari 0,5 dengan nilai signifikasi 0,000 .Hasil pengujian anti image dihasilkan 25 variabel yang digunakan.Dari hasil penelitian yang dilakukan diperoleh hasil bahwa dari 7 Faktor-Faktor penyebab dan dampak banjir yaitu Faktor Alam, Faktor Manusia, Dampak ekonomi, Dampak Sosial, Dampak Lingkungan. Faktor yang paling dominan adalah Faktor Alam, Faktor Manusia dan Dampak ekonomi, untuk meminimalisir dampak tersebut maka harus ada dilakukan dengan mitigasi struktural dan non struktural.

Kata Kunci: Banjir, Penyebab, Dampak.

\section{A. Pendahuluan}

Kota Bukittinggi adalah salah satu kota dari 18 kota/kebupaten yang secara administratif pemerintahan merupakan bagian dari propinsi Sumatera Barat. Secara geografis kota ini terletak antara $100^{\circ} 20^{\prime}-100^{\circ} 25^{\prime}$ Bujur Timur dan antara $00^{\circ} 16^{\prime}-00^{\circ}$ 20' Lintang Selatan dengan ketinggian 780 - 950 meter dari permukaan laut (RT/RW, 2010-2030). Secara administratif pemerintahan kota Bukittinggi memiliki luas wilayah $\pm 25,239 \mathrm{Km}^{2}(2.523,90 \mathrm{ha})$ atau sekitar 0,06 \% dari luas Propinsi Sumatera Barat yang terbagi menjadi 3 kecamatan yaitu kecamatan Guguk Panjang dengan luas 6.831 km2, Kecamatan Mandiangin dengan luas $12.156 \mathrm{~km} 2$ dan Kecamatan Aur Birugo Tigo Baleh dengan luas daerah 6.252 km2 (RT/RW, 2010-2030).

Posisi geografis dan administratif seperti diatas, menyebabkan kota Bukittinggi menjadi salah satu kota strategis di propinsi Sumatera Barat. Kota ini merupakan pintu masuk dan pintu keluar bagi beberapa kota/Kebupaten di propinsi Sumatera Barat menuju kota dan propinsi lainnya seperti kota Pakan Baru di propinsi Riau, Kota tapanuli Selatan di propinsi Sumatera Utara dan kota Muaro Bungo dai Propinsi Jambi. Kondisi geografis dan administratif ini, juga mendorong kota Bukittingi berobah dari wilayah yang pada awalnya merupakan wilayah pertanian menjadi kota perdagangan dan kota wisata. Beberapa wilayah yang pada awalnya daerah pertanian berubah menjadi daerah perumahan (Haluan,1 Maret 2017).Beberapa rumah yang sebelumnya merupakan rumah hunian berubah menjadi hotel. Kota Bukittinggi telah menjadi kota yang padat penduduk dengan peningkatan $1.9 \%$ selama 5 tahun. Namun seiring dengan pertumbuhan, kota Bukittinggi juga mengalami dampak negatif dari pertumbuhan tersebut. Beberapa tahun terakhir kota ini seringkali mengalami banjir serta genangan yang sebelumnya belum pernah terjadi.

Kejadian banjir 22 Desember 2019, memperlihatkan 12 titik di kota Bukittinggi digenangi banjir dengan ketingian $30 \mathrm{~cm}$ hingga 1,5 meter (Antara, 22 Desember 2019) yaitu meliputi; Tabek tuhua, bukik cangang, pasar bawah, tugu adipura, Simpang anak air, jl Sukarno Hatta, dan beberapa lokasi lainnya. Banjir yang terjadi menyebabkan beberapa fasilitas umum seperti mesjid, jalan raya dan perumahan penduduk di beberapa kecamatan digenangi banjir dengan ketingian $30 \mathrm{~cm}$ hingga 1,5 meter (Antara, 22 Desember 2019) dengan kerugian diperkirakan mencapai Rp 250.000.000,- (BPBD Bukittinggi, 2019). Tercatat sejak tahun 2017 terjadi beberapa kali Banjir.

Fakta-fakta diatas menunjukan bahwa banjir menyebabkan dampak yang signifikan kepada berbagai aspek kehidupan masyarakat kota Bukittinggi. Akibat banjir aktifitas sosial dan ekonomi masyarakat terganggu dalam waktu yang lama, aksesibiliats transportasi terhenti, banjir menyebabkan kerusakan kepada berbagai imfrastruktur yang telah dibangun mengalami kerusakan dan tidak dapat berfungsi seperti apa adanya (BNPB, 2013). Karena adanya perubahan iklim dan pertumbuhan penduduk yang tinggi, iklim tropis dan bentuk lahan yang tidak stabil dan dan 
kurangnya pembangunan infrastruktur diperkirakan peristiwa banjir akan semakin sering terjadi (Jayaraman et al, (1997) dan dengan dampak yang lebih besar (Lall dan Deichmann, 2011). Oleh sebab itu harus ada langkah dan upaya berbagai pihak, termasuk perguruan tinggi untuk mengetahui hal-hal yang berkaitan dengan banjir dan ini menjadi latar belakang dari penelitian ini.

Berdasarkan beberapa pertanyaan yang dikemukakan diatas, maka beberapa tujuan yang hendak dicapai dalam penelitian ini adalah sebagai berikut; untuk mengidentifikasi faktor-faktor penyebab dan dampak yang ditimbulkan oleh bencana banjir di kota Bukittinggi. Untuk menganalisis faktor penyebab dan dampak yang ditimbulkan oleh bencana banjir yang paling dominan terjadi di kota bukittinggi. Untuk menentukan langkah dan upaya pengelolaan banjir yang dapat dilakukan .

\section{B. Metodologi Penelitian}

Data yang diperlukan dalam penelitian iniyaitu data dari sumber langsung (data primer) dan data diperoleh dari sumber tidak langsung (data sekunder). Pengumpulan data dilakukan dengan menyebarkan kuesioner pada responden. Melakukan survei dengan menyebarkan kuisioner dengan persyaratan sebagai berikut: Dalam hal ini penentuan kriteria tersebut dapat diuraikan sebagai berikut: 1) Penelitian ini difokuskan pada bencana banjir yang terjadi di Kota Bukittinggi khususnya pada lokasi-lokasi yang pernah mengalami peristiwa banjir secara langsung dalam rentang waktu 5 tahun terakhir; 2) Penyebab dan dampak bencana bajir didasarkan pada kondisi sebenarnya kota Bukittinggi, baik secara geografis, tataguna lahan dan pola hidup masyarakat; dan 3) Penelitian dampak banjir difokuskan kepada bentuk dan jenis dampak dan tidak dikaitkan dengan nilai finansial secara kuantitatif. Metode penelitian yang digunakan dalam penelitian ini adalah Purposive sampling yaitu salah satu teknik sampling non random dimana peneliti menentukan pengambilan sampel dengan cara menetapkan ciri-ciri khusus atau kriteria tertentu ( Sanusi,2011), sehingga tujuan penelitian sesuai dengan yang diharapkan untuk dapat menjawab permasalahan penelitian. Dalam hal ini penentuan kriteria tersebut dapat diuraikan sebagai berikut: 1) Orang-orang atau masyarakat yang berada di kawasan yang terkena banjir; 2) Orang-orang atau masyarakat yang terganggu dengan kejadian banjir tersebut; dan 3) Instansi atau lembaga yang terkait dan berkepentingan, baik teknis maupun non teknis.

\section{Hasil dan Pemabahasan}

Uji Validitas. Berdasarkan uji validitas yang dilakukan dengan bantuan software SPSS menggunakan koefisien korelasi bivariat (product moment) karena teknis korelasi ini digunakan untuk mencari hubungan dua variabel bila data berbentuk internal dan ratio (Sugiono, 2003). Uji ini dilakukan dengan menghitung korelasi masing-masing variabel dari skor total. Disimpulkan bahwa secara statistik hasil dari 45 butir pertanyaan yang terdapat dalam kuisioner adalah valid dilihat dari $r$ hasil untuk tiap item (variabel) bernilai positif dan nilai $r$ hitung $>$ nilai $r$ tabel yaitu 0,164 untuk taraf signifikan 5\% dengan jumlah responden 101 responden $(\mathrm{N}-2=99)$.

Uji Reliabilitas. Dari hasil uji reliabilitas terhadap variabel faktor Penyebab dan Dampak Banjir di Kota Bukit Tinggi dapat ditarik kesimpulan bahwa nilai alpha cronbach'slebih besar dibandingkan dengan nilai minimal cronach alfa 0,6 maka dapat disimpulkan bahwa instrumen penelitian yang digunakan dapat dikatakan reliabel atau handal.

Uji KMO dan Barlett's. Uji kelayakan ini bermaksud untuk mengetahui apakah masing-masing item dapat digunakan untuk pengujian faktor analisis atau tidak. Item- 
item tersebut dikatakan layak diuji apabila nilai KMO dan Bartlett's Test memberikan hasil besar dari 0,05 $(>0,05)$ dengan nilai Sig.a $<0,05$.

\begin{tabular}{|c|c|c|}
\hline Faktor & Hasil Uji KMO & Nilai Signifikansi \\
\hline Penyebab & 0,611 & 0,000 \\
\hline Dampak & 0,808 & 0,000 \\
\hline
\end{tabular}

Dari hasil uji tersebut dapat disimpulkan bahwa variabel dari setiap faktor telah memenuhi syarat dengan nilai KMOMSA dan Bartlett's. Nilai hasil uji pada tabel diatas, nilai KMO dan Bartlett's telah memenuhi syarat yaitu $>0,5$ dengan nilai signifikasi 0,000 hal ini menunjukan bahwa adanya korelasi faktor ataupun variabel dan dapat digunakan untuk dilakukan analisis lebih lanjut.

Analisis Anti Image Correlation. Analisis Anti Image Correlation merupakan model yang digunakan untuk mengetahui layak atau tidaknya sebuah faktor untuk dapat diproses dalam analisis faktor, faktor yang diikutsertakan adalah faktor yang memiliki nilai koefisien korelasi $\geq 0,50$. Nilai MSA dari masing-masing variabel terdapat variabel yang nilai korelasinya kecil dari 0,5 yaitu variabel penyebab $X 1.1$, X1.2, X1.7, X1.9, X2.1, X2.2, X2.3, X2.8, X3.2, X3.5, X3.6, X3.7, X4.1, X4.2, dan X4.3. Variabel dampak X6.6, X7.1 dan X7.3 Hal ini menunjukkan bahwa ke 18 variabel tersebut harus dikeluarkan dan tidak dimasukkan dalam pengujian selanjutnya. Sehingga variabel yang diuji analisis faktor selanjutnya adalah sebanyak 27 variabel.

Analisis Communalities. Analysis Communalities merupakan model yang digunakan untuk mengetahui faktor yang pertama kali terbentuk dalam menjelaskan variance dari sebuah faktor. Jika masing-masing faktor penelitian saling berkolerasi, tentunya akan mempengaruhi akurasi hasil pengujian analisis faktor. Faktor pertanyaan dikatakan berkolerasi apabila nilai communalities besar dari 0,5. Hasil analisis communalities memperlihatkan bahwa terdapat semua faktor dengan nilai $>0,5$. Hal ini bearti menunjukkan semua faktor tersebut bisa untuk dilanjutkan untuk analisis faktor, sehingga untuk analisis faktor dapat digunakan 27 variabel penelitian.

Faktor-Faktor Penyebab dan Dampak Banjir di Kota Bukittinggi. Untuk menganalisis faktor penyebab dan dampak yang ditimbulkan oleh bencana banjir yang paling dominan terjadi di kota bukittinggi. maka selanjutnya pada analisis faktor adalah ekstraksi faktor-faktor ke dalam faktor dengan total variance explainet. Total variance explainet menjelaskan jumlah faktor yang dihasilkan dari hasil extraksi. Tabel Total Variance Explained memperlihatkan bahwa dari 27 variabel dari Faktor Penyebab dan Dampak Banjir di Kota Bukit Tinggi. Penentuan komponen-komponen pembentukan masing-masing faktor didapatkan dari hasil Rotated Component Matrix. Pengelompokan didasarkan pada nilai Loading faktor yang memberikan kontribusi terbesar pada faktor yang dibentuknya. Berdasarkan pengujian Analysis Communalities maka bisa terbentuk 5 faktor baru yang mempengaruhi penyebab dan dampak banjir di kota bukittinggi.

Tabel. Pembentukan Faktor Baru penyebab

\begin{tabular}{|c|c|c|c|}
\hline Faktor & $\begin{array}{l}\text { Nama } \\
\text { Faktor }\end{array}$ & Variabel & Uraian \\
\hline \multirow{5}{*}{1} & \multirow{5}{*}{ Alam } & $\mathrm{X} 1.5$ & Arah pengaliran saluran \\
\hline & & $\mathrm{X} 1.4$ & Pendangkalan aliran air \\
\hline & & $\mathrm{X} 1.6$ & Luapan air limpasan \\
\hline & & $\mathrm{X} 1.8$ & Kelandaian tanah \\
\hline & & $\mathrm{X} 1.3$ & Curah hujan tinggi \\
\hline 2 & Manusia & $\mathrm{X} 2.4$ & Kurangnya kesadaran menjaga kebersihan \\
\hline
\end{tabular}




\begin{tabular}{|l|l|l|}
\cline { 3 - 3 } & & lingkungan \\
\cline { 2 - 3 } & $\mathrm{X} 2.5$ & Adanya bangunan saluran air yang tidak terpelihara \\
\hline & $\mathrm{X} 2.6$ & Penebangan hutan secara liar oleh masyarakat \\
\hline
\end{tabular}

Tabel. Pembentukan Faktor Baru Dampak

\begin{tabular}{|c|c|c|c|}
\hline Faktor & Nama Faktor & Variabel & Uraian \\
\hline \multirow{4}{*}{1} & \multirow{4}{*}{ Dampak Ekonomi } & X6.2 & Terhambatnya kegiatan distribusi \\
\hline & & X6.3 & Terputusnya jalur transportasi \\
\hline & & X6.1 & Kerusakan Jalan dan Jembatan \\
\hline & & X6.5 & Menurunnya pertumbuhan ekonomi \\
\hline \multirow{4}{*}{2} & \multirow{4}{*}{ Dampak Sosial } & $\mathrm{X} 5.5$ & Menyebarnya berbagai jenis penyakit \\
\hline & & $\mathrm{X} 5.1$ & Kerusakan tempat tinggal \\
\hline & & $\mathrm{X} 5.6$ & Kerusakan pada lahan pertanian \\
\hline & & $\mathrm{X} 5.3$ & Susahnya memenuhi kebutuhan \\
\hline \multirow{4}{*}{3} & \multirow{4}{*}{ Dampak Lingkungan } & $\mathrm{X} 7.5$ & Pemicu tanah longsor \\
\hline & & X7.4 & Terganggu keseimbangan lingkungan \\
\hline & & $\mathrm{X} 7.6$ & Terhentinya aktivitas rutin \\
\hline & & $\mathrm{X} 7.2$ & Kerusakan sarana dan prasarana \\
\hline
\end{tabular}

Pada faktor 1 penyebab dan dampak banjir di Kota Bukittinggi ini diberi penamaan faktor alam dan dampak ekonomi, metode pemberian nama menggunakan metode Summated Scale yaitu gabungan dari beberapa variabel dalam satu faktor, bisa berupa nilai rata-rata dari semua faktor tersebut atau nilai penjumlahan dari semua variabel dalam satu faktor. Penamaan pada faktor 1 diambil dari variabel yang paling banyak faktor alam dan dampak ekonomi, selain itu penamaan diambil dari nilai loading tertinggi. Pada faktor 2 penyebab dan dampak banjir di Kota Bukittinggi diberi penamaan faktor manusia dan Dampak Sosial dan faktor 3 diberi penamaan dampak lingkungan, metode pemberian nama menggunakan metode Variabel surrogate yaitu satu variable yang paling dapat mewakili satu faktor maka yang paling mewakili suatu faktor adalah variable yang memiliki faktor loading terbesar.

\section{Penutup}

Setelah dilakukan tahapan-tahapan dalam penelitian mulai dari latar belakang penelitian, tujuan penelitian, kajian literatur, dan analisis data diperoleh bahwa penyebab dan dampak banjir di Kota Bukittinggi terdiri dari Faktor Alam, Faktor Manusia, Faktor Pembangunan, Faktor Peraturan, Dampak ekonomi, Dampak Sosial, Dampak Lingkungan Dari hasil jawaban responden melalui kuisioner penelitian dan dilakukan pengolahan data, diperoleh hasil bahwa faktor penyebab dan dampak banjir di Kota Bukitinggi adalah terdapat 5 faktor baru yaitu Faktor Alam, Faktor Manusia, Dampak ekonomi, Dampak Sosial, Dampak Lingkungan. Faktor yang paling dominan yaitunya Faktor Alam, Faktor Manusia dan Dampak ekonomi. Dari analisis data juga dapat disimpulkan bahwa Faktor Alam, Faktor Manusia memiliki pengaruh terhadap penyebab banjir di kota bukittinggi. Dan dampak banjir sangat berpengaruh terhadap perekonomian

\section{Daftar Pustaka}

Abbas Salim, 1989, Dasar-dasar Asuransi, Edisi Pertama, Penerbit C.V. Rajawali Pers, Jakarta.

Adioetomo Sri Moertiningsih dan Samosir Omas Bulan. 2011. Dasar-Dasar Demografi Edisi Revisi 2. Jakarta: Selamba Empat. 
Ali, Masyhud.2006. Manajemen Risiko:Strategi Perbankan dan Dunia Usaha Menghadapi Tantangan Globalisasi Bisnis.PT. RajaGrafindo Persada. Jakarta.

Andrich, D. (1988). Rasch Model for Measurement. (series: Quantitative Application in the Socials Sciences). Newburry Park, California: Sage Publication.

Anjani, Novia. 2012. Tanggung Jawab. [online]. (http://noviaanjani1593.word press.com/2012/05/28/tanggung-jawab/, diakses tanggal 10 April 2018 pukul 11.00 WIB).

Akhadi, Mukhlis, 2009. Ekologi Energi- Mengenali Dampak Lingkungan Pemanfaatan Sumber-Sumber Energi. Yogyakarta: Graha ilmu

Anonim, 2010. Laporam Akhir: Rencana Tata Ruang Wilayah (RTRW) Kota Bukittinggi Tahun 2010-2030. Pemerintah Kota Bukittinggi.

Amri, S. dan Ahmad, I.K. 2010. Proses Pembelajaran Kreatif dan Inovatif dalam Kelas. Jakarta: PT. Prestasi Pustakaraya.

Arikunto, S. 2010. Prosedur penelitian: Suatu Pendekatan Praktik. (Edisi.Revisi), Jakarta : Rineka Cipta.

Arthur J. Keown, 2000, Dasar-dasar Manajemen Keuangan. Jakarta:Salembe Empat.

Arif Rosydi (2006),B A.W. Coburn, dkk. 1994. Mitigasi Bencana Edisi 2.UNDP.

Astri Lestari (2011), Dampak Sosial Ekonomi dan Sosio-Ekologi Konversi Lahan.

Bakornas PB. 2007. Pedoman Penanggulangan Banjir Tahun 2007-2008. Jakarta.

Budi, Setio (2011). "Ekologi Media": Penerapan Teori Niche dalam Penelitian Kompetisi Media, dalam Ishak, Aswad dkk [ed] 2011. Mix Methodology: Dalam Penelitian Komunikasi. Yogyakarta: Mata Padi Pressindo.

Bogdan, R. dan Taylor, S.J. 1993. Dasar-Dasar Penelitian Kualitatif. Surabaya.

Djamarah, Syaiful Bahri dan Aswan Zain. 2010. Strategi Belajar Mengajar. Jakarta: Rineka Cipta.

Flanagan, R dan Norman, G. (1993). Risk Management And Construction Blackwell Science.

Ghozali, Imam, 2007, Aplikasi Analisis Multivariate Dengan Program SPSS, Universitas Diponogoro, Semarang.

Gilarso, T.(1994). Pengantar Ekonomi Mikro.Jilid 1. Yogyakarta : Kanisius.

Hanafi, Mamduh M dan Abdul Halim, 2005, Analisis Laporan Keuangan, Edisi Kedua, Yogyakarta : STIE YKPN.

H.B. Sutopo. 2002. Pengantar Penelitian Kualitatif. Surakarta : Universitas Sebelas Maret Press.

Imas Kurnia,2012. Dampak bencana banjir lahar dingin terhadap kondisi sosial ekonomi penduduk di Desa Jumoyo Kecamatan Salam Kabupaten Magelang Tahun 2010-2011.http://eprints.uny.ac.id/13921/. Diakses tanggal 30 September 2015, jam 22.15 WITA.

Jayaraman. 1997. Biofilm aerobik axenic menghambat korosi baja SAE 1018 melalui penipisan oksigen.

Muhammad Jafar Hafsah. (2000). Kemitraan usaha : Konsepsi dan Strategi. Pustaka Sinar Harapan Jakarta. 